Longing for Love in Karachi, How Muslim women contend with conflicting global cultural discourses.

\author{
Fauzia Husain
}

Karachi, Pakistan

MA Media and Public Affairs, The George Washington University, 2009

A Thesis presented to the Graduate Faculty

of the University of Virginia in Candidacy for the Degree of Master of Arts

Department of Sociology

University of Virginia May, 2014 


\begin{abstract}
:
This paper focuses on the discursive strategies middle class Pakistani women across two cohorts employ when contending with conflicting global cultural discourses about partnered relationships with men. Examining the schemas that women bring to bear in discussing their romantic relationships with men I shed light on the way in which individuals' strategies are embedded in and informed by the dynamic interplay between global discourses and state power. Older participants' narratives reflected a binary that mimicked the 1970s state framing of globalization in binary terms. Younger participants' narratives reflected the Musharraf government's framing of globalization to favor neoliberalism. Thus both participants narratives imply that Global discourses need to be concretized through state policy and institutional structures before they are reflected in individual subjectivities and that modernization does not advance in fixed stages.
\end{abstract}

\title{
Introduction:
}

This paper focuses on the discursive strategies middle class Pakistani women across two cohorts employ when contending with conflicting global cultural discourses about partnered relationships with men. Examining the schemas that women bring to bear in discussing their romantic relationships with men I shed light on the way in which individuals' strategies are embedded in and informed by the dynamic interplay between global discourses and state power. By doing so, I problematize current sociological understandings of globalization and modernity.

The older cohort of participants in this study came of age at a time when Pakistan's economic policies favored a protectionist stance, which allowed the religious reform minded state extensive control over the public sphere. Since the state pushed forward politically motivated gendering projects undergirded by postcolonial discourses and informed by global discourses of Islamic revival, it concretized a binary relationship between Islam and the west and the strategies of the older cohort mimic this binary nature. On the other hand women in the younger cohort came of age in an era of intensifying economic integration accompanied by neoliberal discourses undergirded by logics of consumption. These structural changes limited the state's power to control the public sphere, especially as the state had mixed success in 
its move towards cultivating a liberal image of Pakistan. These changes in local structures and national ideologies are reflected in the narratives of the younger women, who demonstrate a relative plurality of discursive strategies that adapt both conventional (arranged marriages) and westernized (affect as a basis for marriage) pathways to achieving marriage, yet each of these strategies suggest affinities to neoliberalism.

By highlighting the ways in which global discourses, state agendas, and local structures interact with individuals' strategies across two cohorts I extend the work on globalization and intimacy. Scholars have argued that the scholarship on globalization and intimacy has not been substantiated with sufficient research (Hart 2005). Additionally, scholarly work focusing on globalization more broadly has been critiqued for under theorizing the role of the state (Kim-Puri 2005), and for ignoring the complex effects and multiple origins of globalization through the assumption that globalization entails a west-centric one-way flow of modernization (Martin 1999). I argue that first, globalization should not be conceptualized as a vehicle for one kind of discourse but rather as one of many and at times competing discourses $;{ }^{1}$ and second, that global discourses are meaningful for individual strategies only to the extent that these discourses align with state-led projects that enable discourses to be concretized in the structures of the public sphere. I define the public sphere as not only mediated spaces permitting debate and discussion but also as public spaces of appearance including colleges, jobs, shopping centers, streets, and parks, amongst others. My contention in this paper is that global discourses will impact individuals' schemas to the extent that these discourses align with state agendas that enable discourses to

\footnotetext{
${ }^{1}$ Scholars now recognize Islam as having experienced a global revival since the 1970 s (see Geertz 1968) The term Islamic revival is used in the literature to describe a transnational revitalization of Muslim religious practice (Salvatore and LeVine 2005)
} 
become concretized through the institutions, regulations, laws and policies that structure individuals lives, choices and desires.

Globalization scholars have contended that marriage and family patterns are particularly compelling sites for an investigation of the homogenizing power of globalization (Inkeles 1998). Since romantic love is not predicated on rationality, questions about love provide a key site of cultural knowledge wherein people mobilize several parts of their repertoires in drawing on arguments that seem plausible (Swidler 2001). Consequently love is an arena wherein research participants display wide ranging cultural knowledge. Simultaneously, this is an arena that calls for the use of values that are instrumental in dictating the tenor of individuals' lives through decisions about partnering, committing or splitting up. Drawing on Muslim women's narratives about romantic love and marriage will facilitate an understanding of how people draw on competing schematic frameworks informed by conflicting global cultural discourses to make meaningful decisions. Thus, it is imperative to turn our attention to examining how third world Muslim women make choices about their romantic lives and marital partners in a globalizing world. Additionally, such an inquiry is critical because women's ideas and feelings about marriage can be instrumental in dictating their future career and financial outcomes (Gerson 1981, 2011), and thus are critical to questions of gender equality. Additionally micro level examinations are crucial because individual women's actions, ideas and dispositions can impact larger structures of state (see Mahmood 2004).

In the summer and winter 2013, I interviewed 35 women in Karachi, Pakistan across two cohorts, women over the age of 50 and those under the age of 30 . This research draws on interviews and ethnographic data to explore how women make 
choices about their romantic and marital lives and make sense of competing discourses about romance and marriage.

\section{Globalization and Culture:}

Theories about the impact of the globalization of culture are characterized by two broad trends. Globalization is seen either as leading to homogenization (Sklair 1995, Ritzer 2007) or reactivity and polarization (Barber 1995, Huntington 1993). Both of these views imply that globalization is a specific type of process: west centered, and modernizing (Robertson 1995, Giddens 1994). It either leads to resistance through groups like the Al-Qaeda and the ELF or to change via homogenization or adaptation.

But assuming that globalization processes are always marked by either acceptance or resistance compels us to adopt a rigid view that inevitably devolves into static understandings of women's choices- either women choose modernity or "tradition." Such an understanding renders static and unexamined, the category, "tradition." It fails to unpack the historic processes and global linkages that construct this category "tradition" and that position it in a binary relationship with modernity and/or "the west." By assuming that "tradition" always either vanishes or retrenches as modernity advances we are creating blind spots for ourselves that obscure the ways in which social structures, history and global connections are implicated in individuals' engagement with powerful global discourses. Additionally, such a view elides our ability to see the global as a dynamic field of multiple discourses each structured by local and transnational histories instead of a one way flow of "modernity" from the west to the non-west.

Scholarly work that does break free of this dichotomous understanding of modernity and "tradition" has focused on how questions of gender are complicated by 
the increasingly rapid transnational flow of cultural ideas and practices in an increasingly global era (Razavi and Jenichen 2010, Rinaldo 2011, Moghadam 2009). Scholars addressing gender and the globalization of cultural discourses have concentrated attention on veiling (Hefner-Smith 2007, Scott 2010), on feminist social movements and NGOs (Rinaldo 2011) and on women's education (Connel 2010). While these studies have done much to inform us about how women are enabled or constrained by structural and rhetorical forces in various contexts, they have not been concerned with extending our understanding of the way in which global logics inform the discursive schema individual women employ in negotiating their relationships or of the national structures and emotions that guide women's choices of schema. Thus the focus of scholarly work in this arena has primarily targeted public and collective responses to conflicting global cultural discourses, leaving unattended questions about responses at the individual level.

\section{Globalization and Intimacy:}

Questions of intimacy and globalization are complicated by problematic views about globalization and development. Scholars see the transition from arranged marriages to what social historians have called "companionate marriage," as the cornerstone of the transition from "tradition" to "modernity." Such transformations are described by sociologists and anthropologists as reflecting a move away from a "kin centered" social order towards an "individual centered" one (Fox 1975, Giddens 1992; Xu and White 1990). Advancing modernity with its attendant transformations in notions of individuality, youth culture, consumption and romance decenter the importance of kin ties raising the importance of individual desire and leading to a shift in marriage systems that were rooted in economic and sexual arrangements to 
one that necessitates the emotional work of intimacy and sexual desire, expressed through romantic love (Giddens 1990).

Thus, the literature on intimacy and globalization presumes that modernity creates conditions where individuality and independence require young people to establish marriages based on romantic love (Ahearn 2001, Coontz 2005, Yan 2003). This contention is based on the assumption that modernity with its attendant demands of mobility requires people to rely on new ways of establishing trust in relationships,

Trust in persons is not focused by personalized connections within the local community and kinship networks. Trust on a personal level becomes a project, to be 'worked at' by the parties involved, and demands the opening out of the individual to the other. Where it cannot be controlled by fixed normative codes, trust has to be won, and the means of doing this is demonstrable warmth and openness (Giddens 1990).

However Hart (2007) argues that scholars are assuming romantic love is a sign of modernity despite a paucity of research on this issue. The understanding of romantic love as a sign of modernity is a Eurocentric view (Jankowiak ed. 1995, Lipset 2004), additionally; modernity does not entail a unidirectional and consistent endpoint of social evolutionary development (Hart 2007, Lipset 2004, Appadurai 1996). Thus, scholars' understanding of romance and modernity has entailed a problematic view of cultural change. It has presumed that modernity advances in fixed developmental stages and that people have a closed set of choices in the face of these changes. Whereas cultures are in a constant state of flux and "intimacy and love transform in relation to other forms of expression, including those, which are economic and ideological. (Hart 2007).”

\section{Theoretical Framework: Sociology of Intimacy:}

The concerns of globalization and intimacy scholars align with central questions in sociology. A dominant concern of sociology since the inception of the field has been to understand the decline of tradition in the face of advancing 
modernity (Comte, Weber, Durkheim, Simmel ${ }^{2}$ ). Over the last three decades this preoccupation has included a sociological investigation of the transformation of intimacy in the postindustrial western context. Following a path laid by the Frankfurt school Lasch (1979), Hochschild (2003), and Kipnis (2003) have examined the blurring of boundaries between the commercial and the intimate, questioning the impact of this blurring on individual freedom. Examining romantic love more specifically, Illouz (1997) argues that the "deep affinities" romantic love bears with the "experience of the sacred" constitute the centrality of romantic love in western society. Drawing on Durkheim, she argues that advancing secularization leads to the migration of sacred experience from religion proper to other domains of culture, such as romantic love. Thus she explains that in the western context romantic love is characterized by liminality, a transitory phase where the market replaces religion in providing the meaning and rituals that undergird individuals' abilities to retreat into sacred "hot moments."

But this explanation of the centrality of romantic love hinges on secularization and begs the question: how is a specific notion of love becoming globalized (Padilla et al. 2007) in tandem with global religious revivals (D'Souza 2002)? How do people contend with competing global discourses that on the one hand are seen as modernizing (Giddens 1991) and on the other array themselves against modernization and the west (Geertz 1971)? Extending Illouz's model of romantic love to a nonsecular context, that of Pakistan, this paper will examine how the globalization of an ideology that emphasizes, "affect as a basis of marriage" (Hirsch and Wardlow, eds. 2006) interacts with competing cultural discourses propelled by the Islamic revival

\footnotetext{
2 See also Parsons' (1951) discussion of pattern variables.
} 
(Geertz 1971, Salvatore and LeVine 2005). Thus I examine two periods of Pakistan's history, each of which framed globalization differently.

Thinking about how individuals' narratives about intimacy reflect globalizing discourses necessitates varying the degree to which groups have been implicated in the processes of globalization. How do different framings of globalization shape the way in which people think about romance and intimacy- the medium through which the "west," and the discourses that array themselves against it, have battled for dominance. One way to accomplish this variation is to examine the narratives of women across two different eras, controlling for social class and nation state. In the section that follows, I briefly describe each of these periods before turning to a description of my methods.

\section{First period: Islamization and the Zia Era 1977-1988:}

General Zia-ul-Haq established himself by overthrowing the "un-Islamic" government of Z. A. Bhutto. As a military dictator who had over-thrown a democratically elected government, Zia had an urgent need to legitimize his rule. For this purpose the Islamic revival movement that was ongoing in several global contexts since the 70 s provided a ready-made tool, one that provided the dictator with allies such as the Jamaat-e-Islamic (an extreme right wing religious political party), assorted religious fundamentalists and feudal landlords, all of whom had been threatened by democracy. Jaffar (2005) argues that Zia needed a visible canvas on which to demonstrate the success of his Islamizing project and for this purpose the General turned his attention to women, specifically middle class women who had become increasingly visible in the public sphere and were seen as "western."

By arguing that it was un-Islamic for women to work outside the home Zia harnessed centuries of anxieties about colonial penetration. "Westernization" 
symbolized by women's presence in the public sphere signified the erosion of "tradition" and Islam. Thus Islam became coded as "authentic" and "traditional" culture where the "west" was coded as corrupt and foreign. In this way, Zia's project relied on a west/Islam modernity/"tradition" binary that was mobilized by colonial powers in an effort to justify imperial projects (see Spivak 1988, Abu-Lughod 2002).

In order to implement his campaign for reform Zia launched a number of written and unwritten policies that particularly impacted middle class women. This included legal reforms such as the infamous Zina ordinance (1979) that transformed adultery and fornication into crimes with a maximum sentence of death by stoning. Unwritten policies included a call for communal vigilantism that resulted in a particular focus on women's morality in public spaces (Mumtaz and Shaheed, 1987) and also allowed policemen to harass unmarried men and women sighted in public together (Jaffar 2005).

Since the period encompassed protectionist economic policies, the state exclusively controlled banks, telecommunications, television and radio. Most universities and colleges were also state owned. Thus, the state enjoyed considerable power to impose policies that discouraged women from flourishing in these spaces (for a detailed history and analysis of this period see Jaffar 2005). In sum, the Zia era concretized the colonial era binary between the west and Islam, it did so by focusing reform efforts primarily on middle class women. The concretization of the binary was facilitated by economic protectionism, which lent the state considerable control over key institutions of the public sphere.

\section{Second period: Liberalization and the Musharraf Era: 1999-2008}

In the second period General Pervez Musharraf seized power from the democratically elected government of Nawaz Sharif. Since Sharif was a protégé of 
Zia-ul-Haq, Musharraf's bid to legitimate military rule did not focus on Islamic reform. Instead Musharraf highlighted economic and governance failure as key sites in need of reform through liberal rule. Thus Musharraf cultivated an image of himself and his government as facilitating liberalization through economic reform and the protection of women. This posture was symbolized by the state's decision to align itself with the US in the war against terror.

Musharraf's efforts at ideological liberalization included the reduction of the sentence for extra marital sex from death to 10 years imprisonment. Additionally, the police were no longer permitted to harass unmarried couples in public spaces. However Musharaf's success at ideological reform was ambivalent at best, this can be seen both through his failures to really do away with Zia era laws such as the Hudood ordinance and through his unsavory comments about rape victims. ${ }^{3}$ Additionally, Pakistan's alignment with the US in the war against terror has also been subjected to criticism for its ambivalence (Hadar 2002). Thus the move towards a more liberal ideology was marked with ambivalence.

Musharraf's economic policies entailed the deregulation of finance, the deregulation of media and telecom and a considerable increase in foreign direct investment. Each of these policies facilitated the reduction of state control over the public sphere. Private banks, media firms, malls, parks and restaurants began to flourish. Additionally, during this period, a number of private colleges and universities had already expanded educational opportunities for men and women.

The opening up of private spaces within the public sphere, facilitated as they were by liberalizing economic policies and increases in foreign direct investment allowed neoliberal discourses to take root during the Musharraf era. Thus the second

3 "Outrage at Musharraf Rape Remarks." BBC News. BBC, 16 Sept. 2005. Web. 11 Apr. 2014. 
period entails the beginning of the concretization of a second global discourse, one that prioritizes reduced state control and competition by private firms.

\section{Methods:}

In order to understand how different framings of globalization shape the way in which people think about romance and intimacy I interviewed two groups of women whose overall characteristics capture these two eras in Pakistan. The first group constituted women who came of age during the Zia era, while the second group of women came of age during the Musharraf era. Since Zia's policies had focused primarily on middle class women both groups of participants interviewed as part of this study were middle class women.

Field site: The decision to focus this research in Karachi was similarly motivated by a number of considerations: First, Karachi is Pakistan's largest, most ethnically and religiously diverse city. With the largest port located here, Karachi is also the most industrialized of Pakistan's urban settlements, and is home to the head offices of numerous corporations and media organizations. The city is home to the largest proportion of middle class Pakistanis. Second, Karachi was ranked $62^{\text {nd }}$ on A.T. Kearney and The Chicago Council on Global Affairs,' global cities ranking. While Sassen's conceptualization of global cities has more to do with the impact and the integration of these metropolis' on the global financial system, Karachi's position as an admittedly low ranking global city does provide it with a unique position within Pakistan. As the center of Pakistan's financial sector and through its integration in the global economy, Karachi is powerfully placed to exert an influence on the rest of the country.

\section{Sample:}


The total sample size was $\mathrm{N}=(35)$. Interviews were continued until the data became saturated, in other words until no new concepts or categories were emerging in respondents' narratives. The sample population was varied by cohort and included the following sub samples:

1) $n=(15)$ women over the age of 55 who self identify as Muslim. This constitutes women born prior to 1958 .

2) $n=(20)$ women aged between 18 to 30 years who self identify as Muslim. This constitutes women born after 1980.

Participants were recruited via snowball sampling with initial requests for participants circulated via colleagues and friends and supplemented with requests posted on Karachi based Facebook groups. Both samples consisted of middle class, Muslim, female respondents currently residing in Karachi, Pakistan. While the middle class is a smaller proportion of Pakistan's population, it is represented in larger numbers in the metropolitan city of Karachi. For the purposes of this study, "middle class" was operationalized by education level, with current college enrollment or some college education signifying middle class status for these respondents.

\section{Data and analyses:}

Data was collected via in-depth, semi-structured interviews conducted in Karachi, Pakistan in the summer and winter of 2013. Each interview was conducted in person by the researcher who is fluent in Urdu and English, permitting participants to speak in whichever language they preferred. Interviews were recorded on tape and transcribed for analysis. Each interview lasted an average of 2 hours, with the shortest one taking one hour and the longest seven hours.

Following the blended coding method proposed by Lichterman (2002), interview transcripts were analyzed via a combination of grounded theory (Charmaz, 
2006) and extended case methods (Burawoy, 1998). Blended coding seeks to synthesize observations in the data with theory of large social and cultural forces. In the first stage, interview transcripts were analyzed via open coding techniques to allow new categories to emerge. These categories were used to develop thematic memos, which also incorporated concepts derived from existing research on romance. In the second stage thematic memos were used to guide analyses and identify patterns in respondents' narratives within and across each respondent category. During analysis, attention was focused not only on emerging patterns within respondents' narratives but also on what was unusual or distinct so analysis was not guided solely by expectations but was alert to discrepancies and contradictions. Discussing a few interview transcripts with a graduate student field methods group ensured reliability.

The analysis was also guided by Pugh's (2013) identification of the four types of information generated by interview transcripts, "the honorable, the schematic, the visceral and meta-feelings." This mode of analysis relies on the understanding that emotions help to explain how people use specific cultural tools rather than other available ones. Researchers have long noticed that people tend to have conflicting ideas about cultural issues, and scholars (Illouz, 2008) contend that emotion is the vector that guides which schema will be accessed. Sensitivity to respondents' emotional maps then enabled a reconstruction of the "landscapes of meaning" (Reed, 2011) that respondents occupy. Thus Pugh's framework for accessing meaning was used as a strategy to build a model of culture in this context. Accordingly, the analysis in this paper relies on understanding how the participants in this study resolved the tensions arising from a perceived discrepancy between romantic ideals and realities.

Findings: Discursive Strategies: 
The narratives of the two cohorts differ dramatically in their strategic use of global discourses in the arena of intimacy. These differences are summarized in table 1 below:

\begin{tabular}{|l|l|l|}
\hline & Older cohort & Younger cohort \\
\hline Strategies & Successful relationships: & All relationships: \\
& Compromise and submission & Multiple: \\
& Problematic relationships: & $\dot{\text { Shopping }}$ \\
& Binary & $\mathbf{P}$ Privatization \\
& Islam vs. reject Islam & \\
\hline
\end{tabular}

Table 1: Discursive strategies.

The narratives of the older cohort differ in the context of successful versus problematic relationships. Successful relationships call for compromise, according to these women. Problematic relationships call for either a rejection or an acceptance of the intimate relationship and draws on either an acceptance or a rejection of religion as framework of meaning. The younger cohort on the other hand departs from this binary strategy by drawing simultaneously on both poles of the Islam/west dichotomy in creative ways. The younger women deploy a number of complementary strategies in their relationships with men. The strategies of each cohort are discussed in detail below, following a brief discussion of the cohort differences in descriptions of ideal relationships and understandings of duty.

\section{Ideals and strategies: Older cohort:}

Older women who see their marriages as successful describe idealized relationships in ways that blend "companionate marriage" with an understanding of differentiated roles for men and women. Friendship is identified as an important component in marriage but women are seen as subordinate to men. However, older women contend that idealized thoughts about marriage are impractical; marriage, they argue, never 
takes the shape we wish it to, thus successful marriages call for compromise and submission. In this arena, older women see their duty as residing within their roles as wives and mothers and as extending to their in-laws.

Contrastingly, women in the older cohort who saw their marriages as problematic responded to these problems in one of two ways: either they drew on Islam as a source of comfort and a framework for action, or they rejected religion altogether and harnessing the language of personal growth and self-actualization chose to end their marriages and seek love. Thus unhappy marriages called forth two kinds of responses: retreating into piety or rejecting religion. In this way the strategies of the older cohort signified a binary form that mimics the binary concretized during the Zia regime.

\section{Younger cohort:}

Contrastingly, younger women displace duty from its anchor in marriage and argue that Islam calls upon their duties as daughters rather than as wives. The younger women's narratives are undergirded by anxiety about being able to fulfill their duties as workers and daughters once they become wives. This anxiety leads younger women to contend that they are seeking men who will give them "space" and let them "breathe." Since younger women also perceive men as stalled, they do not expect to find partners able to provide the kind of companionship and understanding they desire. Thus younger women operate from a framework blending duty and desire, wherein duty shifts from its mooring within marriage and attaches itself to women's kin. Since younger women resemble older women in thinking that ideals are unachievable, they subordinate their desire for companionate marriages to the culturally prioritized ideal of achieving marriage at all, regardless of its ability to live up to ideals. The anxiety to achieve marriage calls forth a plurality of strategies from 
younger women. These strategies appear to bear affinities to the neoliberalism that took root during the Musharraf era.

\section{Confronting Problems: the older cohort and binary responses:}

Older participants' who saw their marriages as problematic provided narratives about romance and marriage that signified a binary strategy for contending with conflicting discourses. These women either drew on Islam as a template for action or they rejected this template and drew instead on discourses prioritizing "selfactualization" and "personal growth."

Maheen, a 57-year-old housewife had an arranged marriage soon after she graduated from Home Economics College in Karachi in the early 80s. She said that she had tried valiantly to prevent this marriage but had failed. Maheen talked about her subsequent struggles to maintain a sense of her own individuality as she lived with her husband's extended family in what is locally known as a joint-family system. She explained that from a young age she had seen Islam as a source of comfort and a template of action in her life. But she also felt that a lack of knowledge about Islam in her youth had hampered her ability to concretize the strategies for action suggested by religion. Thus, in her 50s she joined a women's Quran study group:

Maheen: when I did the Quran course it was such a beautiful thing for me Fauzia. I was crying and thinking I wish I could have done it before I got married, my life would have been very different.

Interviewer: How would it have been different?

Maheen: because I would have known what the Quran was telling me to do and with my husband, it teaches you, it teaches you so many things and it would have given me so much more $\operatorname{sabr}^{4}$ (patience).... the Quran suggested lots of nice things, ek tau, (for one thing,) you have to be thankful to your husband, which I was not, back then because there was not much to (laughs) be thankful for, I was emotionally not, you know feeling good but the Quran teaches you that the wife's you know, I mean,

\footnotetext{
${ }^{4}$ Sabr is a difficult word to translate. Most people translate it as patience but considering the way it is used by people I think one could translate sabr as a combination of patience and resilience, since patience alone implies passivity and people does not always use sabr as a passive concept.
} 
it doesn't teach you to submit it says you have your rights and I suppose, having my rights, no. I think having the knowledge would have made me more stronger to face them (her in laws), I could not face them or make my situation better because I did not have the knowledge of the Quran. The Quran is very good for that because the Quran is so authentic that no one can challenge that.

In contrast, Samina, 51, works in an NGO concerned with women's development projects. At the age of 19, Samina's parents arranged for her to marry a second cousin. Faced with her husband's constant infidelity, Samina decided to end this marriage in her 30s and to enroll in a Women's Studies course at a nearby university. Samina subsequently married and divorced another man and at the time of the interview had ended a yearlong affair with a childhood friend. Samina's narrative does not see Islam as a guide for action; instead, she utilizes feminist discourse and the language of self-actualization to explain her choices:

(I was) struggling to build myself, to build myself in a constructive way, (to tell myself) that all is not lost, that wife is not a status you can rely on, because it can be lost, (that) mother is not a status you can rely on, because, look, they don't even ask me how I am. For me, except for the stretch marks on my belly, there is no evidence that I have children... If you ask about my use of the term: "self actualization"- strangely just before my second marriage- I was searching for, self help- it made me realize, and (since I was) studying gender, that a woman when she is consciousitized, (and made to realize) that she is not just an object to produce a baby, to become a wife, that she is an individual, that she is a human being, she has a brain, she can contribute, more than just children and running a house, she can contribute, these things made me realize that no there is more of me that I have to discover.... In retrospect I say I was constructing myself. At the time if someone would criticize me I would internalize it, I would ask others, "is this true?" "How true is it?" Then I saw the lie in it, the rubbish. And at times I would see (that) it was true too. Then I would ask, "is this how I am or can I change?" Then I would change.

Women in the older cohort also drew on conflicting discourses in binary ways when narrating what ideal relationships with men look like, Mehnaz, 55 is a housewife whose father had pressured her in her early 20s to pursue a professional 
career in business. But, she asserts that she had no wish for a professional life and instead wished to marry her cousin. Mehnaz says her father was forced to accept her decision when she had repeated mental breakdowns in business school. Looking back on her youth she describes her ideal romantic partner:

At that time one didn't think in terms of marriage- whether a guy was good marriage material or not, we just didn't think that way. I did like gentlemen, liked Christopher Plummer, in the Sound of Music especially, someone dignified, with self respect and who was kind and loving and had complete control of every situation, who was gentle, loving and kind. But the thing is this that one has to be very realistic because in real life these things are not there.

Mehnaz's prioritization of a domestic life for herself is reflective of the Zia regime's discourse about the appropriate role for women. Her description of the ideal man depicts men as benevolent controllers and keepers of women, which again echoes the structure facilitated by the Zia regime. Although she describes Christopher Plummer as a romantic ideal, the rest of her interview drew heavily on Islam as a template for male and female action.

So I think our men sadly lack knowledge of how to act towards their wife. They think that because Allah taala has given them a degree higher than the wife, the whatever you call it, the degree, is because of the qawam hain (they are qawam) husbands are qawam, qawam means, sort of qiyaam which means standing, they should stand up for their wives, in the sense for support, financial support, moral support, emotional support. I feel very sorry because of the lack of knowledge. We are Muslims after all why call us Muslims if we don't even know what Islam is about? ... Our men behave as if the wife is like a shoe. After they marry her they have a very condescending attitude, sort of a domineering attitude and they think it's a right Allah has given him, which is totally wrong.

In this extract, Mehnaz is arguing that the reason men adopt domineering modes of behavior towards their wives is because they do not know enough about Islam. Thus Islam is the appropriate template for action. This prioritization of Islam also led to Mehnaz's arguments, later in the interview that women should be more graceful and allow their husbands' to obtain second wives. 
In contrast, Kaukab, 62, a retired educationist, describes, "genuine love" as the foundation of an ideal romantic relationship, because, she asserts, genuine love leads to personal growth. Kaukab says that love and respect for her father motivated her, in her early 20s; to agree to marry a man she had never met. When she did meet her husband, on the day of their wedding, she was horrified because, "I had no feeling for him and you know, you can't force feelings." Consequently, in her 30s Kaukab decided to divorce her husband even though there were no outstanding reasons to do so- her decision was based simply on her lack of romantic feelings towards him. She describes her readings in western philosophy as motivating these actions:

Betrand Russel was my start, it (his book on marriage) inspired me that marriage is so beautiful and it becomes so ugly, why, because we allow it to persist in this ugly form, so we don't grow, we remain in filth, because nothing is more beautiful than feelings, its all a game of feeling, so that feeling has to be protected and respected, then you have to honor that, and if even one of them (a married couple) no longer feels that way then to prolong it is to live in hell. So even though people may realize this, they get stuck because of some fear, as a human being they don't grow, they don't enjoy life, because it's a negative cycle that catches them in its grip, doesn't allow them to spread.... what is required is sincere love, mature love, this is very necessary to drive life's car together, without this there can be no happy marriage. ... so this is where I want to share my experience with you, that, when you are alone, single, then your own personality, your own ego, is there, there's a desire to move forward and everything, but when you catch a root in another person then from inside you start to change, it is not apparent, but you feel committed to somebody, you want to care for somebody, then slowly, slowly that person becomes like a mirror, then you start seeing yourself in that mirror, as a human being, you start to develop and to a large extent you become a better person because of that sincere love. (Kaukab 62)

Kaukab's narrative rejects Islam as a template for action, “I don't believe there is a thing called God, sitting up there and watching you," instead, she utilizes the language of personal growth and molds her understanding of ideals to a concern for individual development.

When faced with problematic situations in their intimate relationships with men, women in the older cohort choose one of the global discourses about intimate 
relationships, either they choose Islamized discourses, arguing that Islam is a template for male and female action within intimate relationships. Or they harness the language of personal growth and choose to end marriages they see as hampering their selfactualization. These choices may have been structured by Zia era policies that sought to relegate women to the chaddar and chardivari (veil and four walls of the home) and cited Islam as an authentic template for cultural action. By concretizing a binary between Islam and the west, the Zia era appears to have prevented the possibility of blending these discourses. Since the Zia era framed these discourses as conflicting with each other, it seems likely that this framing is related to older women's discursive strategy of choosing one instead of drawing on both.

\section{Confronting uncertainty, the younger cohort and multiple strategies:}

Since the primary ideal for young women was the culturally prized ideal of marriage, these women subordinated the ideal of finding love-based companionate marriages to that of achieving marriage at all. Although one young woman totally rejected arranged matches, all of the other young women in my sample asserted that while a "love marriage" was preferable to an arranged one, in the face of uncertainty, it was better to be simultaneously open to both arranged and love matches. Thus it appears that global discourses about love are subordinate to local ideals about the importance of marriage in this context.

Unlike the binary strategies of the older cohort, the narratives of the younger cohort were characterized by a proliferation of strategies for dealing with the problematic situations in their intimate relationships with men. These strategies blended both poles of the Islam/west binary in multiple ways and appear to bear affinities to neoliberal logics. Four of these strategies are described and their resemblance with neoliberal logics are discussed below: 


\section{Shopping: Competition and Efficiency:}

"...we were hanging (out) at the mall, he asked, "what next?" I said, "lets go to Seaview and walk barefoot on the beach," just to check his reaction-- is he flexible or not. He was only talking about himself and that was a problem, so I kept listening, but I didn't like it, so I didn't go out with him again" (Reema 26 Marketing).

Adopting the strategy of shopping entails an effort by women to maximize chances of achieving marriage through meeting multiple men simultaneously. This strategy allows women to save time by making quick judgments and quick decisions about the men they go out with. By employing the strategy of shopping women are evaluating specific men in relation to the broader supply of men thus rendering the marriage market as a competitive field where discerning women must make efficient choices.

This strategy appears to bear an affinity with neoliberal logics of efficiency, rationality and competition.

Since this strategy involves an effort to meet multiple men simultaneously instead of becoming gradually intimate with one, shopping also requires the selfmanagement and self-control that scholars have argued emerge in neoliberal regimes (Bourdieu 1998). Thus shopping involves controlling emotions by keeping expectations low, working on self-presentation and physical appearance, and becoming skillful at "reading people."

I see what kind of person he is, I'm mechanical, I play a game, its like a client you try to see what kind of client is it, if he's quiet- I play (it) cool but if he's casual I also come in between (i.e. push myself forward)- try to get introduced. If I'm interested I'll make a move- it depends on my level of interest and it depends on the vibe I'm getting.... You can tell if its going somewhere, not by time, but by the conversation- like, its not going anywhere, Good time chalay jaraha hai (the good time is just going on and on). So I look for signs, "should I stop?"... I have learned that its better to not have any expectations- over time I have tried to understand and implement it, now I understand these things. (Reema 26 Marketing).

\section{Blending: Flexibility:}


The strategy of blending entails the effort to harness two modes of coupling by being simultaneously open to arranged matches as well dating.

"I am feeling that I don't think that just seeing people will get me somewhere, either you find someone and that's very lucky if it works out or you get your parents to put you in that- people are still open to arranged marriages.....even amongst my friends... Girls are worried about wasting time" (Amina, 26, corporate consultant).

At times women keep their dating secret from their parents, at other times parents are in on the secret but pretend not to know what is going on. Thus parents and women work together to accomplish the culturally prioritized goal of marriage. By blending both modes of coupling women increase their chances of achieving marriage and also split the labor of evaluating men with parents. This strategy calls for flexibility, not only in being open to both arranged marriages and love matches simultaneously but also in adapting each of these modes to personal needs.

"If I met a man, I would tell him to approach my family. That's a way to know if he is sincere or not. If my family introduces me to someone, then they know that I will want some time to get to know him first. Maybe go out for dinner or a movie. So love is not love and arranged is not arranged. It's all about filtering." (Fizza 29, Government servant).

Thus this strategy appears to bears an affinity with neoliberalism through its demand for flexibility and responsiveness to structural conditions.

\section{Privatization: Self Control:}

So I was going through this whole phase where I myself was thinking ... Maybe it is me... So I also started considering ... this guy .... I gave it a shot without really... I didn't want to overcommit because I just, I never felt that thing with him ... I did that whole self talk, "okay, this guy is nice, he's not that bad,..." so you know the logical things that you should look into, keeping fantasy aside, right?

In an uncertain marriage market women seek to discipline, control and manage themselves. This entails emotion work when women try to become involved with men 
they do not have feelings for as well as emotion work to overcome the pain resulting from failed romantic relationships. Instead of blaming culture, structure, society or the men they have been involved with women focus effort on evaluating and transforming themselves, thus the problem of finding a husband is seen as a private problem with an individualized solution. Through privatization, self control and reflexivity this strategy appears to bears an affinity with characteristics prioritized by neoliberal regimes.

\section{Aligning religion with desire:}

“obviously I believe in God ... I have complete faith- but ... I don't know if I believe in a lot things, like the dupatta for example ...I mean guys are not wearing caps everywhere so why do we have to cover our heads? .... I want to read the Quran for myself I feel like I need an explanation. When God has said that I've explained everything then how am I suppose to just believe ....if I cant understand it then I feel like that's not God's word." Arifa 22, student.

Coming of age in an era when neoliberalism starts to take root in Pakistan appears to have led young women to evaluate religion through the lens of utility and rationality. Religio-cultural elements that are seen as incapable of withstanding this scrutiny are either explicitly discarded or reinterpreted in order to bring them in line with women's desires. Thus younger women argued that dating was compatible with Islam by claiming that dating was rooted in sunnah (Islamic practice):

"Hazrat Khadija married him because she liked him, that was a totally different scenario that a woman is asking out a man, that is our beloved Holy Prophet, we need to follow him, that was a sort of dating." Mehnaz 28, Designer.

Women who claimed to be more observant of religious rituals such as praying redefined dating by referring to a specific practice they called, "halal dating." Halal dating involves abstaining from being alone with a man through the use of chaperones or public venues. Within this kind of dating, relationships are deliberately limited to the extent of friendliness and romance is constrained, "you can hug, but no skin touch 
is allowed, no sitting on laps, no flirting. You have to dress decently and modestly, your arms must not show," (Nudrat, 22, student).

Drawing on religious sources in creative ways, halal daters simultaneously transform both dating and religion. Considering the marriage of Hazrat Khadija to the Prophet as dating is a very wide stretch, yet, interpreting sunnah in this way brings religion in line with contemporary desires while simultaneously taming these desires to bring them in line with faith by excluding romance and sexuality from the domain of dating. Halal dating can be seen as resembling Islamic banking, the reconfiguration of a contemporary model to Islamic ideals that in the process transforms both. By aligning religion with rationality or by transforming dating into halal dating, young women appear to be harnessing neoliberal logics of adapting and responding to local conditions. Just as global restaurants adapt their menus to specific cultures, young women adapt the discourses they draw on to bring them in line with their personal desires.

\section{Conclusion:}

In this paper I have sought to demonstrate the ways in which the state, and the economy interact with globalized cultural discourses to impact individuals' strategies of action. I have argued that the older women in this study were constrained in their choices for romantic relationships through the state's definition of the role of women and through its control of the public sphere. Since the state allowed the police to harass unmarried couples during this time, the possibility of dating was limited:

"because we were cousins it was very nice, in the sense it was safe and secure, we didn't feel we were doing something wrong, because you know it was family and phupi (my aunt) knew that we were together and where we were going so it was safe." (Mehnaz 55, housewife). 
A majority of the women in the older cohort had arranged marriages and argued that compromise and submission are the only pathways to success in marriage. Most older women who had had love based marriages said they were only able to spend time with their fiancés in their parents' homes or at other peoples' weddings. Older women who saw their marriages as problematic reflected an either/or strategy towards globalized Islamic discourses. Either, these women embraced piety and saw Islam as a template for action or they rejected religion altogether.

On the other hand, younger women I have argued, came of age in an era that permitted increased opportunities for romantic relationships and for visibility in the public sphere. But these relative freedoms did not appear to lead to a switching from the Islam to the west pole of the binary, instead younger women's narratives reflect increased anxiety about achieving marriage and harness several strategies to ensure greater chances of finding a husband. These strategies draw on self-management, flexibility, efficiency and adaptation and I argue that they bear affinities to the logics of neoliberalism, which were able to take root in the Musharraf era shift from protectionism to market deregulation. 


\section{References:}

- Adams, Laura L. 2007. "Globalization of Culture and the Arts." Sociology Compass 1(1):127-142 (http://search.proquest.com/docview/61691467?accountid=14678).

- Ahearn, L. 2001. Invitations to love: literacy, love letters, and social change in Nepal. Ann Arbor: University of Michigan Press.

- Appadurai, A. 1996. Modernity at large. Minneapolis: University of Minnesota Press.

- Barber, Benjamin R. 1996. Jihad vs. McWorld. New York, NY: Ballantine Books.

- Beck, Ulrich, Giddens, Anthony, Lash, Scott (1994) Reflexive Modernization. Politics, Tradition and Aesthetics in the Modern Social Order. Stanford University Press

- Burawoy, Michael. 1998. "The Extended Case Method." Sociological Theory 16(1):4-33 (http://search.proquest.com/docview/61606917?accountid=14678).

- Charmaz, Kathy. Constructing Grounded Theory : a Practical Guide Through Qualitative Analysis. London: Sage Publications, 2006. 
- Connell, Raewyn. 2010. "Kartini's children: on the need for thinking gender and education together on a world scale." Gender \& Education 22, no. 6: 603615. Academic Search Complete, EBSCOhost (accessed December 9, 2013).

- Coontz, S. 2005. Marriage, a history. New York: Viking Press.

- Delanty, Gerard 2003. 'Consumption, Modernity and Japanese Cultural Identity: The Limits of Americanization.' Pp. 114-33 in Global America? The Cultural Consequences of Globali-zation, edited by Ulrich Beck, Natan Sznaider and Rainer Winter. Liverpool, UK: Liverpool University Press.

- D' Souza, Leela. 2002. "Globalization and Religion. the Emergence of Fundamental Movements." Journal of Social Sciences 6(2):85-94 (http://search.proquest.com/docview/60462794?accountid=14678).

- Fox, G.L. 1975. Love-match and arranged marriage in a modernizing nation: mate selection in Ankara,Turkey. Journal of Marriage and the Family 37, $180-93$

- Friedman,Thomas. 1999. The Lexus and the Olive Tree. New York: Farrar Straus Giroux.

- Gayatri Spivak. 1988. "Can the Subaltern Speak?” From Nelson and Grossberg, eds. Marxism and the Interpretation of Culture. Macmillan.

- Geertz, C. (1971). Islam observed : religious development in Morocco and Indonesia. Chicago: University of Chicago Press.

- Gerson, K. (1985). Hard choices : how women decide about work, career, and motherhood. Berkeley: University of California Press.

- Gerson, Kathleen. 2010. The unfinished revolution: How a new generation is reshaping family, work and gender in America. New York: Oxford University Press.

- Giddens, A. 1990. The consequences of modernity. Stanford: University Press.

- 1992. The transformations of intimacy. Stanford: University Press.

- Gottdiener, Mark. 1995. Postmodern Semiotics. Oxford, England: Blackwell.

- Hadar, Leon T. "Pakistan in America's War against Terrorism: Strategic Ally or Unreliable Client?" Cato Institute. Cato Institute, 8 May 2002. Web. 21 Apr. 2014.

- Hannerz, Ulf 1990. 'Cosmopolitans and Locals in World Culture.' Pp. 237-51 in Global Culture: Nationalism, Globalization and Modernity, edited by Mike 
Featherstone. Newbury Park, CA: Sage Publications.

- Hart, Kimberly. 2007. "Love by Arrangement: The Ambiguity of 'Spousal Choice' in a Turkish Village." Journal of the Royal Anthropological Institute 13(2):345-362 (http://search.proquest.com/docview/61698452?accountid=14678).

- Held, David, Anthony Mcgrew, David Goldblatt and Jonathan Perraton 1999. Global Transformations: Politics, Economics and Culture. Stanford, CA: Stanford University Press.

- Hochschild, A. Russell. (2003). The commercialization of intimate life: notes from home and work. Berkeley: University of California Press.and

- Holton, Robert. 2000. "Globalization's Cultural Consequences." The Annals of the American Academy of Political and Social Science 570:140-152 (http://search.proquest.com/docview/61792991?accountid=14678).

- Huntington, Samuel 1993. 'The Clash of Civilizations.' Foreign Affairs 72: $22-50$.

- Illouz, E. (1997). Consuming the romantic utopia: love and the cultural contradictions of capitalism. Berkeley: University of California Press.

- Inglehart, Ronald and Christian Welzel. 2005. Modernization, Cultural Change and Democracy: The Human Development Sequence. Cambridge. Cambridge University Press.

- Inglehart, Ronald. 1997. Modernization, Cultural cHANGE AND THE persistence of Traditional Valyes.” American Sociological Review, vol. 65. $19-51$

- Inkeles, Alex. 1998. “One World Emerging? Convergence and Divergence in Industrial Societies. Bourlder and Oxford: Westview Press

- Jafar, Afshan. 2005. "Women, Islam, and the State in Pakistan." Gender Issues 22(1):35-55 (http://search.proquest.com/docview/60012475?accountid=14678).

- Jameson, Fredric. 1991. Post modernism, or the Cultural Logic of Late Capitalism. Durham, NC: Duke University Press.

- Jankowiak, W. (ed.) 1995 Romantic passion: a universal experience? New York: Columbia University Press. 
- Jennifer S. Hirsch and Holly Wardlow, eds. 2006. Modern Loves: The Anthropology of Romantic Courtship and Compan-ionate Marriage. Ann Arbor: The University of Michigan Press. ISBN 978-0-472-06959-0.

- Kaplan, Richard L. 2002. 'Blackface in Italy: cultural power among nations in the era of globalization.' Pp. 191-211 in Global Culture: Meida, Arts, Policy, and Globalization, edited by Diana Crane, Nobuko Kawashima and Ken'ichi Kawasaki. New York, NY: Routledge.

- Kellner, Douglas. 2002. Theorizing globalization. Sociological Theory 3, (11): 285-305, http://search.proquest.com/docview/60452483?accountid=14678 (accessed December 9, 2013).

- Kim-Puri, H.J. 2005. “Conceptualizing Gender-Sexuality-State-Nation: An Introduction." Gender \& Society 19: pp. 137-159.

- Kipnis, L. (2003). Against love: a polemic. New York: Pantheon Books.

- Lasch, C. 1979. The Culture of Narcissism: American Life in an Age of Diminishing Expectations. New York:

- Levi-Strauss, C. 1949. The Elementary Structures of Kinship. Translated by Rodney Needham. Boston: Beacon Press.

- Lichterman, Paul. 2002. "Seeing Structure Happen: Theory-Driven Participant Observation." Pp. 118-145 in "Seeing Structure Happen: Theory-Driven Participant Observation."U Minnesota Press (http://search.proquest.com/docview/60033806?accountid=14678).

- Lila Abu-Lughod. 2002. "Do Muslim women really need saving? Anthropological reflections on cultural relativism and its others." American Anthropologist 104.3: pp. 783-790.

- Lipset, D. 2004. Modernity without romance? Masculinity and desire in courtship stories told by youngPapua New Guinean men. American Ethnologist 31, 205-24.

- Mahmood, Saba 2005. Politics of Piety: The Islamic Revival and the Feminist Subject. Princeton University Press.

- Mark B. Padilla, Jennifer S. Hirsch, Miguel Munoz-Laboy, Robert E. Sember, and Richard G. Parker, eds. 2007. Love and Globalization: Transformations of 
Intimacy in the Contemporary World. Nashville: Vanderbilt University Press. ISBN 978-0-8265-1584-1.

- Martin, Randy. 1999. Globalization? The dependencies of a question. Social Text 17 (3): 1-14.

- Moghadam, V. 2009. Globalization \& Social Movements: Islamism, Feminism, and the Global Justice Movement. Lanham, MD: Rowman \& Littlefield.

- Mumtaz, K., \& Shaheed, E 1987. Womenin Pakistan: Two Steps Forward, One Step Back? London: Zed.

- Nancy Smith-Hefner. 2007. "Javanese Women and the Veil in Post-Suharto Indonesia.” Journal of Asian Studies, Vol. 66, No. 2, pp. 389-420.

- Rinaldo, Rachel. 2011. "Muslim Women, Moral Visions: Globalization and Gender Controversies in Indonesia." Qualitative Sociology 34(4):539-560 (http://search.proquest.com/docview/1125217918?accountid=14678).

- Ritzer, George 2007. The Globalization of Nothing 2. Thousand Oaks, CA: Pine Forge Press.

- Ritzer, George and Todd Stillman 2003. 'Assessing McDonaldization, Americanization and Globalization.' Pp. 30-48 in Global America? The Cultural Consequences of Globalization, edited by Ulrich Beck, Natan Sznaider and Rainer Winter. Liverpool, UK: Liverpool University Press.

- Robertson, Roland 1995. 'Glocalization: Time-Space and HomogeneityHeterogeneity.' Pp. 25-44 in Global Modernities, edited by Mike Featherstone, Scott Lash and Roland Robertson. London: Sage Publications.

- Rubin, Gayle. 1986. "The Traffic of Women: Notes on the Political Economy of Sex." Nueva Antropologia 8(30):95-145 (http://search.proquest.com/docview/60974472?accountid=14678).

- Salvatore, Armando, and Mark LeVine. Religion, Social Practice, and Contested Hegemonies : Reconstructing the Public Sphere In Muslim Majority Societies. Houndmills, Basingstoke, Hampshire: Palgrave Macmillan, 2005.

- Shahra Razavi and Anne Jenichen, "The Unhappy Marriage of Religion and Politics: Problems and Pitfalls for Gender Equalit.” Third World Quarterly 31 (2010): 833-50

- Sklair, Leslie 1995. Sociology of the Global System. Baltimore, MD: The 
Johns Hopkins University Press.

- Sklair, Leslie. 2001. The Transnational Capitalist Class. Cambridge: Blackwell.

- Smith, Anthony 1990. 'Towards a Global Culture?' Pp. 171-91 in Global Culture: Nationalistm, Globalization and Modernity, edited by Mike Featherstone. London: Sage Publications.

- Stiglitz, Joseph E. 2002. Globalization and Its Discontents. New York: Norton.

- Swidler, A. (2001). Talk of love: how culture matters. Chicago: University of Chicago Press.

- Taylor, Charles. 2001. “Two Theories of Modernity.” In Gaonkar, Dilip P., ed. Alternative Modernities 172-196. Durham and London: Duke University Press

- William R. Jankowiak, ed. 2008. Intimacies: Love and Sex across Cultures. New York: Columbia University Press. ISBN 978-0-231-13436-1.

- Xu, X. \& M.K. Whyte 1990. Love-matches and arranged marriages: a Chinese replication. Journal of Marriage and the Family 52, 709-22.

- Yan, Y. 2003. Private life under socialism: love, intimacy and family change in a Chinese village, 1949-1999. Stanford: University Press. 